\title{
Authoritarian Capitalism and Its Impact on Business
}

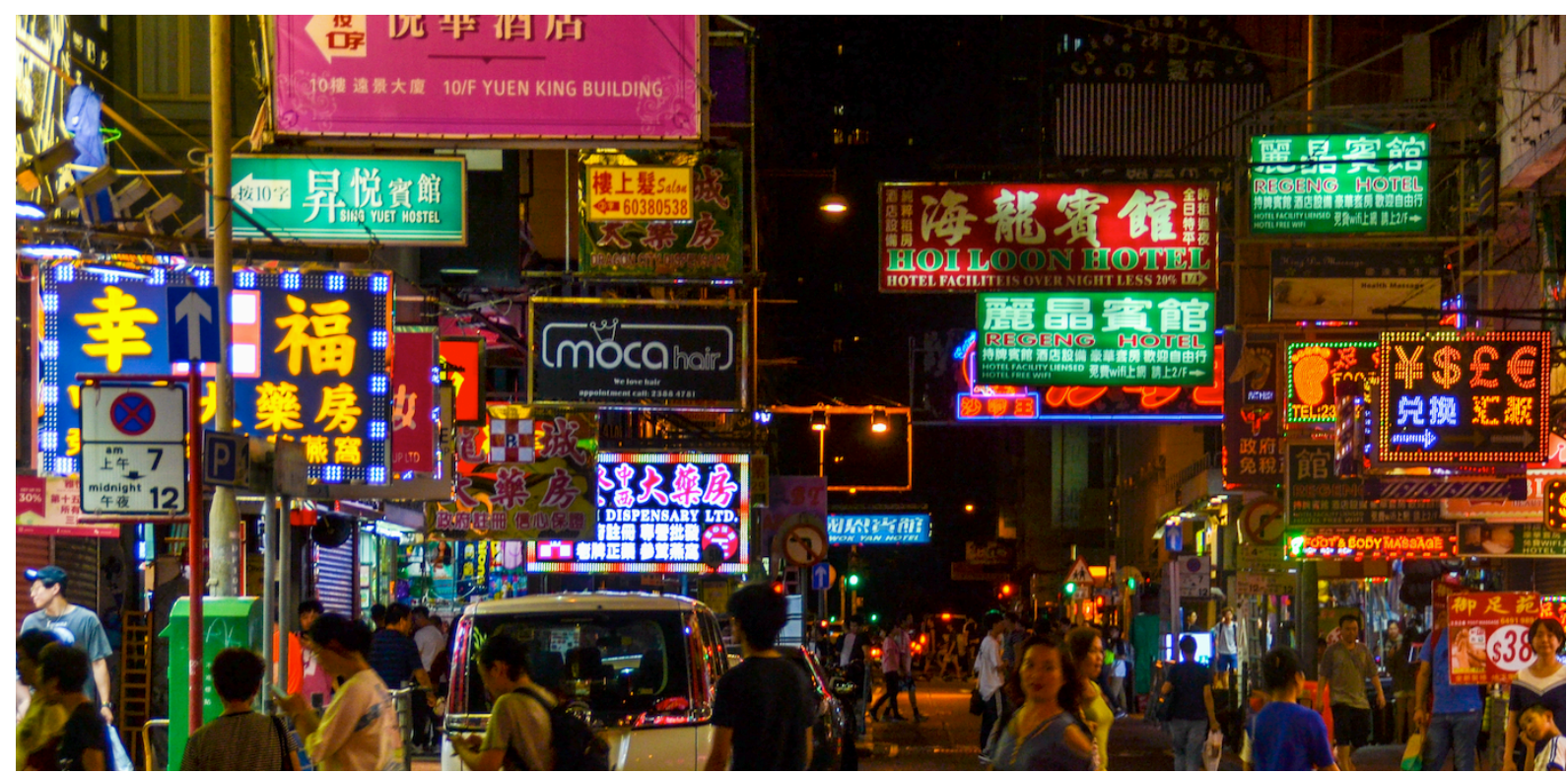

\section{Daniel Kinderman}

Associate Professor and Director of European Studies

Department of Political Science \& International Relations

University of Delaware

\section{Symposium on Authoritarianism and Good Governance}

\author{
Muqtedar Khan (Ed.)
}

International Institute of Islamic Thought | February 2021

DOI: $\underline{\text { http://doi.org/10.47816/02.001.23 }}$ 
Authoritarian Capitalism and Its impact on Business Environment Daniel Kinderman

\section{Introduction}

The global political order has undergone multiple sea changes in recent decades. With the collapse of the Soviet Union, liberal democracy was widely seen as the "End of History."1 "Free market capitalism looked to have permanently carried the day,"2 and it was thought to be only a matter of time until the world converged on this model. By the 2010s, the tide had turned, and a democratic recession ${ }^{3}$ shattered this liberal-democratic triumphalism and the assumptions that had underpinned it.

The earthquakes of Brexit and Trump are two manifestations of the deeper structural forces which have rendered liberal democracies increasingly unstable, divided, and polarized. 4 Meanwhile, China's rise suggests an alternative model that embraces capitalism while rejecting or severely restricting political and civil liberties. Without democracy, Singapore has risen to become one of the world's most prosperous and dynamic economies. In both Hungary and Poland, democratic backsliding has taken place under right-wing populist rule.

The authoritarian capitalist model is contentious. Proponents of liberal democracy maintain that the authoritarian capitalist model is dysfunctional. Prominent scholars claim that democracy is better for growth 5 and that growth in authoritarian countries such as China will run out of steam unless they liberalize politically. ${ }^{6} \mathrm{~A}$ decade ago, one leading commentator wrote, "Free markets provide those who participate in them with long-term advantages that state capitalism can't match."7 
In this essay, I inquire into the relationship between authoritarian capitalism and business and set out to answer the following questions: What happens to the business environment under authoritarian leadership? Is there a trade-off between authoritarianism and the climate for business? Does democratic recession in liberal democracies have any notable downsides for business?

To answer these questions, I draw on indicators measuring civil and political liberties and corruption on one hand, and the ease of doing business, global competitiveness, and innovation on the other hand. The evidence suggests two crucial findings. First, key business indicators in China and Singapore have improved significantly despite these countries' persistent authoritarianism. Second, key business indicators in Hungary and Poland have stayed constant or improved, despite growing authoritarianism in these two countries during the past decade. In short, the authoritarian capitalist model does not appear to be dysfunctional or have significant drawbacks for large segments of business.

The section below provides a quick gloss of authoritarian capitalism in Singapore, China, Hungary, and Poland.

\section{Authoritarian Capitalism}

What is authoritarian capitalism?

This question is difficult to answer because the group of authoritarian capitalist countries is heterogeneous and not clearly defined. Authoritarian capitalism can include features such as authoritarian shareholding, predatory nationalizations, the extraction of private rents using the state as a tool, the reduction of economic pluralism 
through the alignment of economic and political interests, as well as state capture by particularistic interest groups and the creation of state dependence of economic actors. These features can result in the erosion of the rule of law and the colonization of the state by the ruling elite, 8 but softer authoritarian capitalist models can maintain impartial bureaucracies and the integrity of the rule of law.

\section{A defining characteristic of} authoritarian capitalism is the presence of a capitalist economy on one hand along with the absence or erosion of democracy and civil liberties on the other hand. Authoritarian capitalism must be carefully distinguished from public ownership, which is unproblematic insofar as state companies are democraticallycontrolled and accountable. There is nothing per se wrong with public ownership; on what grounds is ExxonMobil, Royal Dutch Shell, or BP preferable to Norway's Equinor/Statoil? Especially in a situation in which competition has been weakened and corporate power is highly concentrated-a situation which arguably pertains to the contemporary United States ${ }^{9}$-there is little to recommend the status quo in comparison to democratically-controlled public ownership.

\section{I identify four examples of} authoritarian capitalism: China, Singapore, Hungary, and Poland. These countries vary in several ways. Singapore, under the rule of the People's Action Party, is widely considered an example of 'soft' authoritarianism: ${ }^{10}$

Singapore's limited democracy has been singularly successful in producing the national development it has been 
deliberately designed to produce.

It is remarkable that the PAP

rulers of Singapore, enjoying

almost total power given them by

the political system, have

administered it without

succumbing to any abuse of

power, arbitrary rule, corruption,

mismanagement or disregard for

the interests of Singaporeans.

They have always ruled the island state with exceptional integrity, dedication, and respect for the rule of law. ${ }^{11}$

According to another scholar,

Singapore has been successful because it has been smart in a dual sense. It has been pragmatic and also technologically empowered.... Singapore policymaking has become smart ... Singapore has designed and implemented global best practices in a broad range of areas. $^{12}$

China, under President Xi Jinping, is an "authoritarian capitalist" model that “mixes developmental with predatory elements and remains highly interventionist"13; "hard" authoritarian model which combines "hardened political repression ... with very marginal economic reforms"14; a "pragmatic authoritarian" model,, 15 and a "party-state capitalist" model characterized by "party-state encroachment on markets; a blending of functions and interests of state and private ownership; and politicized interactions with foreign capital."16

Poland and Hungary are both members of the European Union and at least nominally democracies with multiparty elections. Hungary, under Prime Minister Viktor Orbán, presents a stark example of democratic 
deconsolidation. Orbán is an individual with an "absolute will to power" and a "ruthless chess player of power politics." ${ }^{17}$ Over the past decade, Orbán has, with an iron fist, launched a “perpetual war against liberal Western values," constructed a "carefully veiled authoritarian system,"18 and a "postcommunist mafia state."19 Orbán's "constitutional coup" 20 has tilted the political system strongly in favor of his ruling party Fidesz, which also exerts tight control over the country's news media. Orbán's illiberal revolution has weakened the independence of the judiciary ${ }^{21}$ and resulted in an exceptional concentration of power. ${ }^{22}$ Critics have charged that since pluralism is an essential prerequisite of democracy, Orbán’s “moralized antipluralism" 23 is not just illiberal, it is anti-democratic.
Poland's right-wing populist Law and Justice (PiS) government, under the leadership of Jarosław Kaczyński, has often been compared to Orbán’s Hungary because of the democratic backsliding that has taken place in both countries. In power since 2015, the PiS government has put pressure on oppositional media outlets, weakened minority rights, and dismantled institutional checks and balances through changes to the judiciary, in particular the Constitutional Tribunal. ${ }^{24}$

\section{Indicators of Democracy, Civil}

\section{Liberties, and Corruption}

This section shows how China, Singapore, Hungary, and Poland score according to widespread indicators of democracy, civil liberties, and corruption. We begin with the Freedom House ratings for civil liberties and political rights, which range from 1 to 7 , "with 1 representing the greatest degree 
of freedom and 7 the smallest degree of freedom." 25

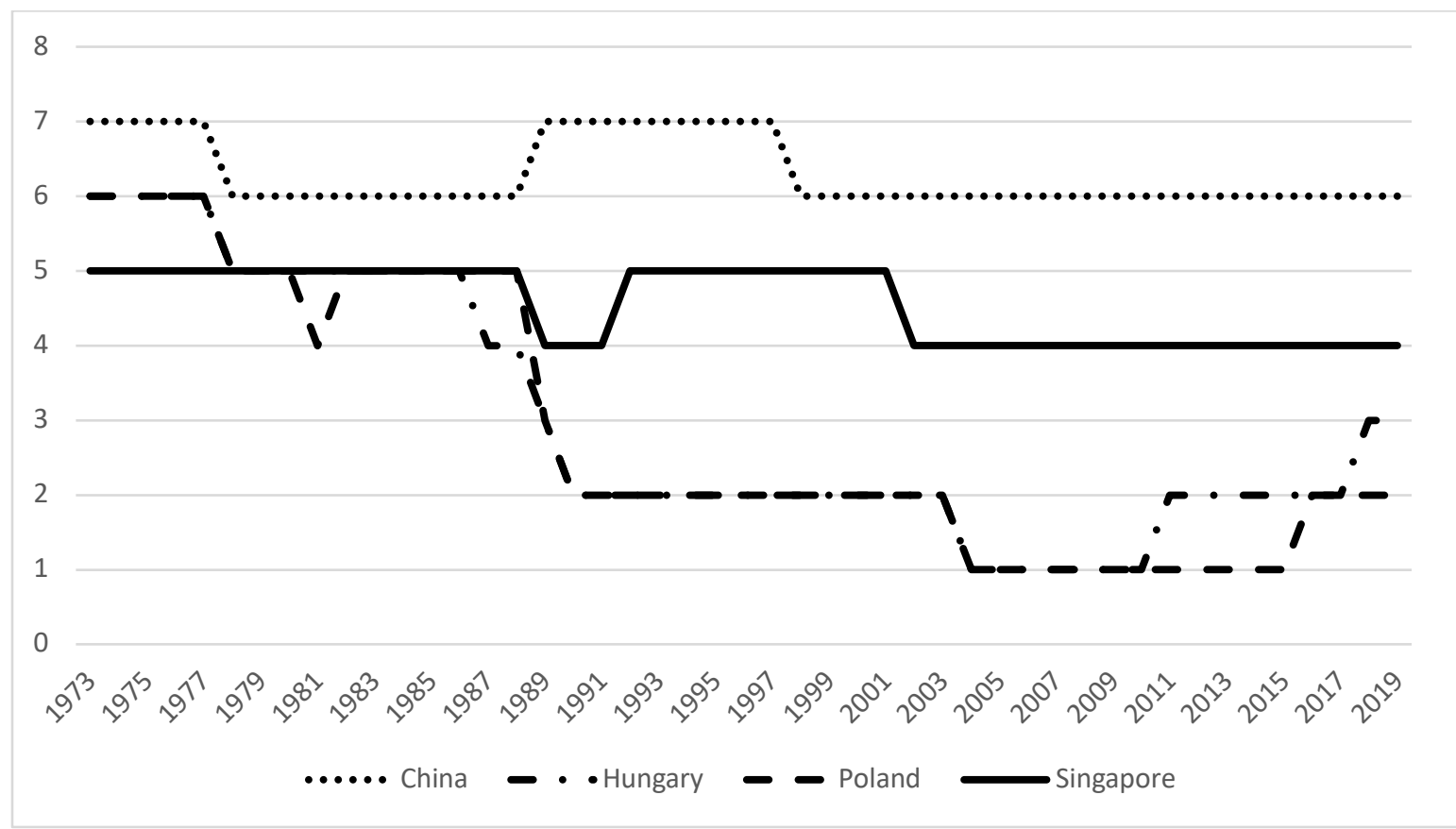

Figure 1: Freedom House Civil Liberties, 1973-2019

Source: Freedom House

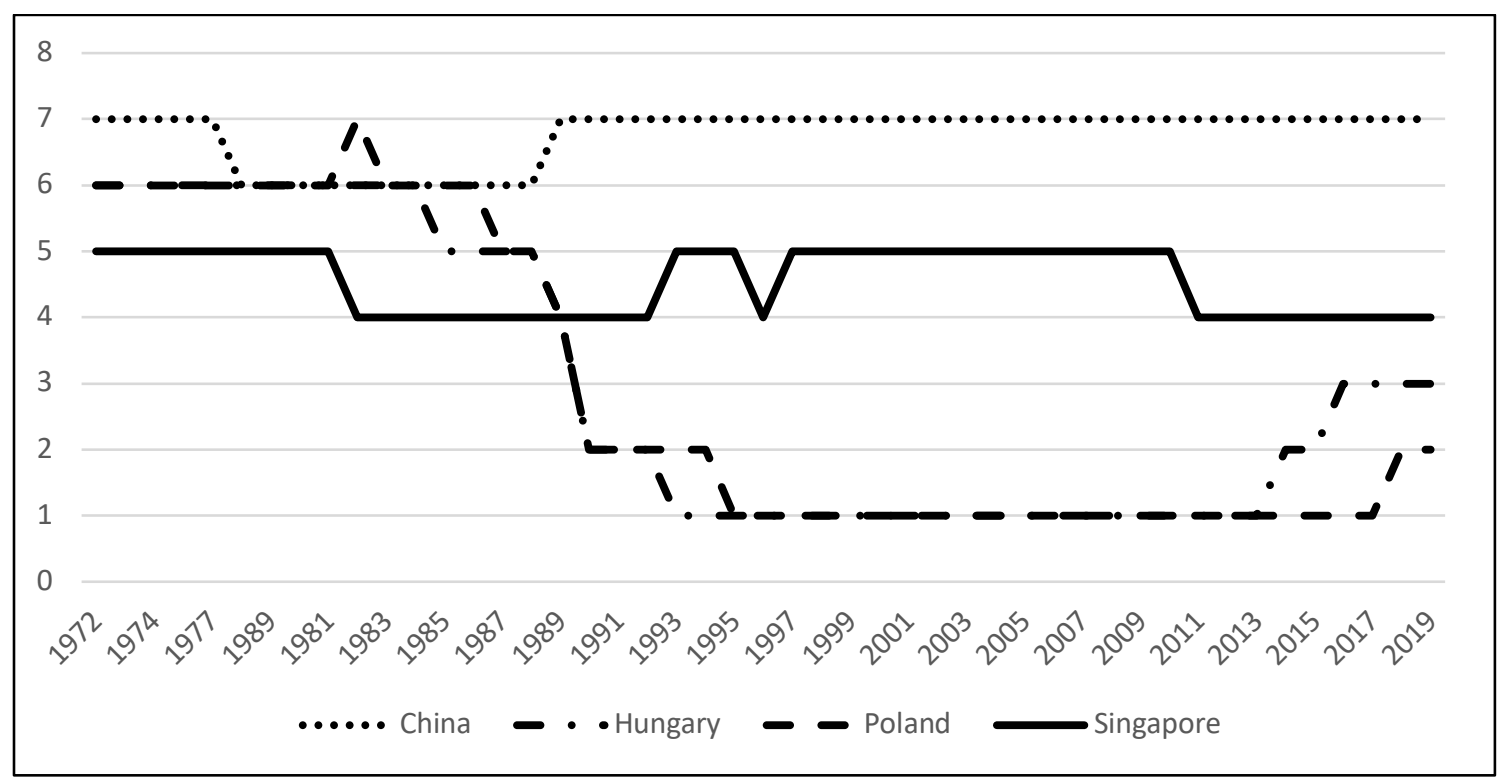

Figure 2: Freedom House Political Rights, 1972-2019 


\section{Source: Freedom House}

As we can see in Figures 1 and 2, China has remained in the Not Free category regarding both civil liberties and political rights over the past five decades. Singapore, by contrast, is Partially Free. From the 1990s through the 2010s, Poland and Hungary had become fully Free, but by the 2010s, both were regressing under right-wing populist rule, so that by 2016-2018, Hungary was Partially Free in both categories. In Poland, the movement has been smaller, but in the same direction.

Next, we examine Transparency International's Corruption Perceptions Index, which "uses a scale of zero to 100, where zero is highly corrupt and 100 is very clean." 26

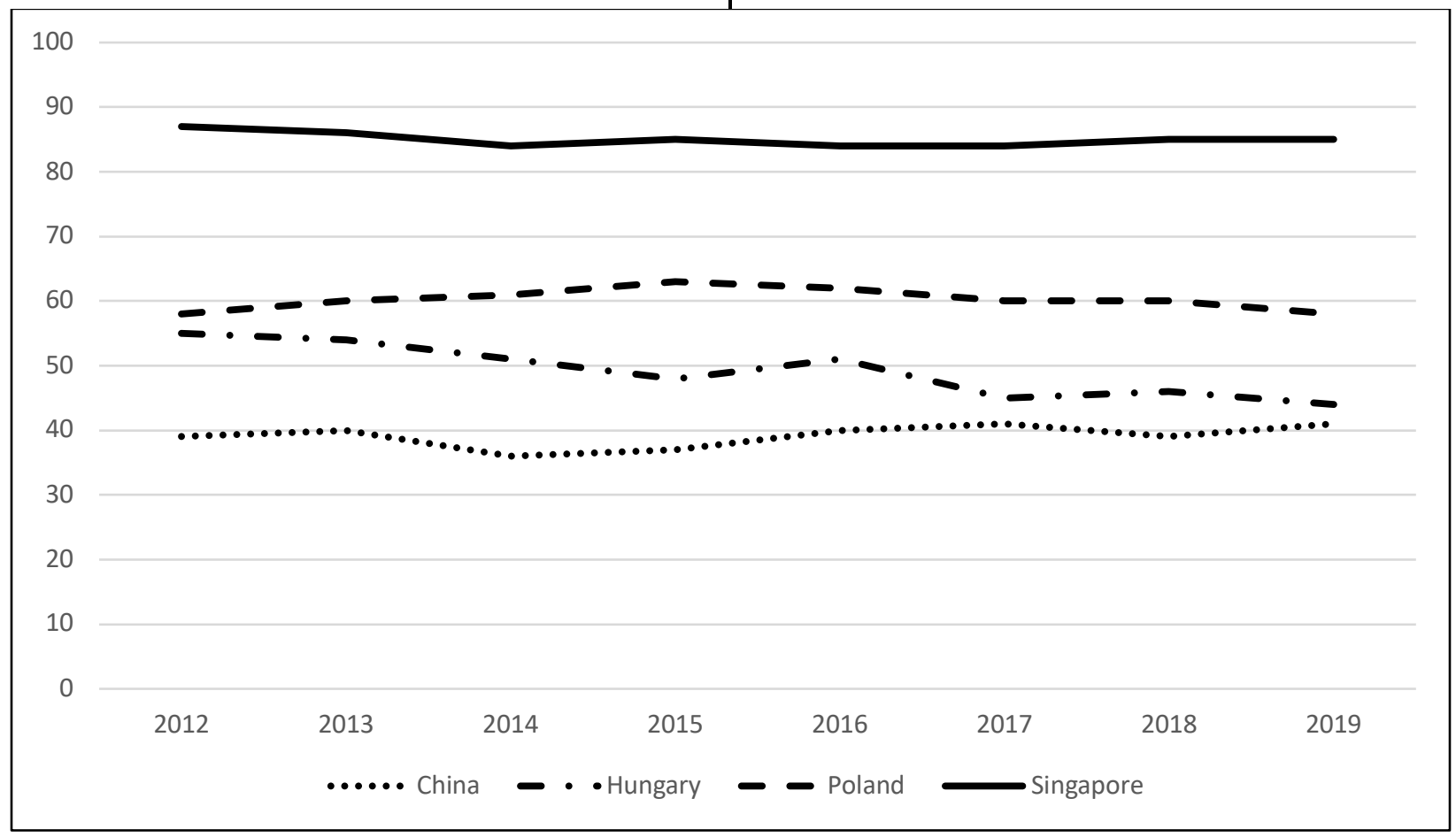

Figure 3: Transparency International Corruption Perceptions Index, 2012-2019 Source: Transparency International 
Singapore has consistently been one of the least corrupt jurisdictions in the entire world. China is much more corrupt. Under right-wing populist rule, corruption has increased in both

Hungary and Poland-quite dramatically in the former, and to a lesser extent, but still noticeably in the latter. Although there is substantial variation within the group of authoritarian capitalist nations, these regimes score poorly when it comes to political rights and civil liberties. Singapore is squeaky clean, but the other three countries have problems with corruption. Authoritarianism has had an effect on politics and society in these countries, but has it also had an adverse impact on the business environment? We will find out in the next section.

\section{The Business Environment under} Authoritarian Capitalism: The Ease of Doing Business, Competitiveness, and Innovation

Leading commentators have suggested that authoritarianism adversely affects the business environment-however, is that really the case? We begin with the World Bank's Doing Business index, which provides a commonly used measure of business regulation, the ease at which small domestic firms can conduct business in the largest business city in each economy. Figures 4, 5, and 6 show the progression of China, Hungary, Poland, and Singapore. Figures 4 and 5 provide the raw scores, while Figure 6 provides these countries' rankings. The World Banks' methodology for the Doing Business index changed between 2011 and 2014, which explains the two-year data gap between Figure 4 and Figure 5 . 


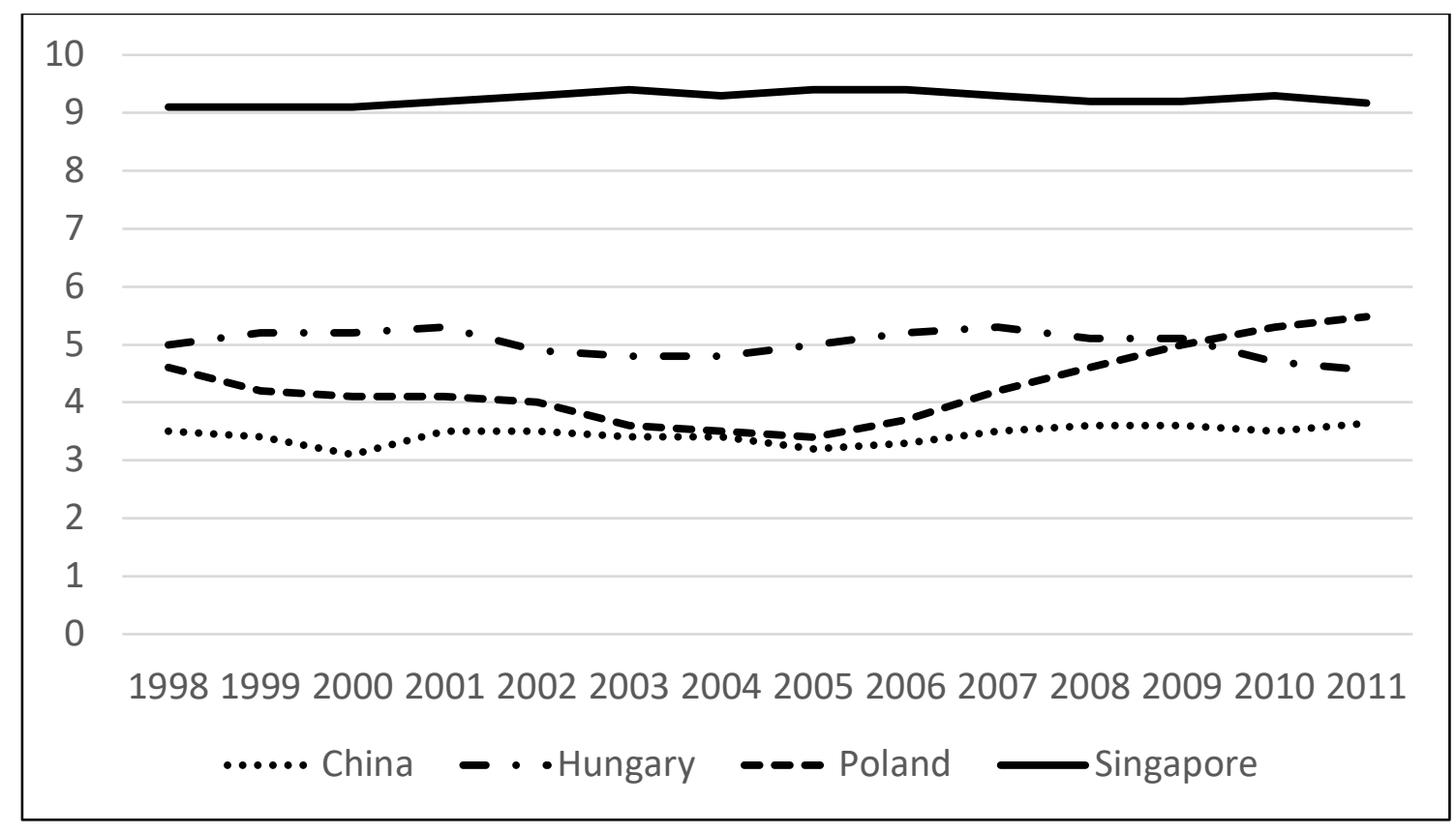

Figure 4: World Bank's Doing Business Index, 1998-2011

Source: World Bank

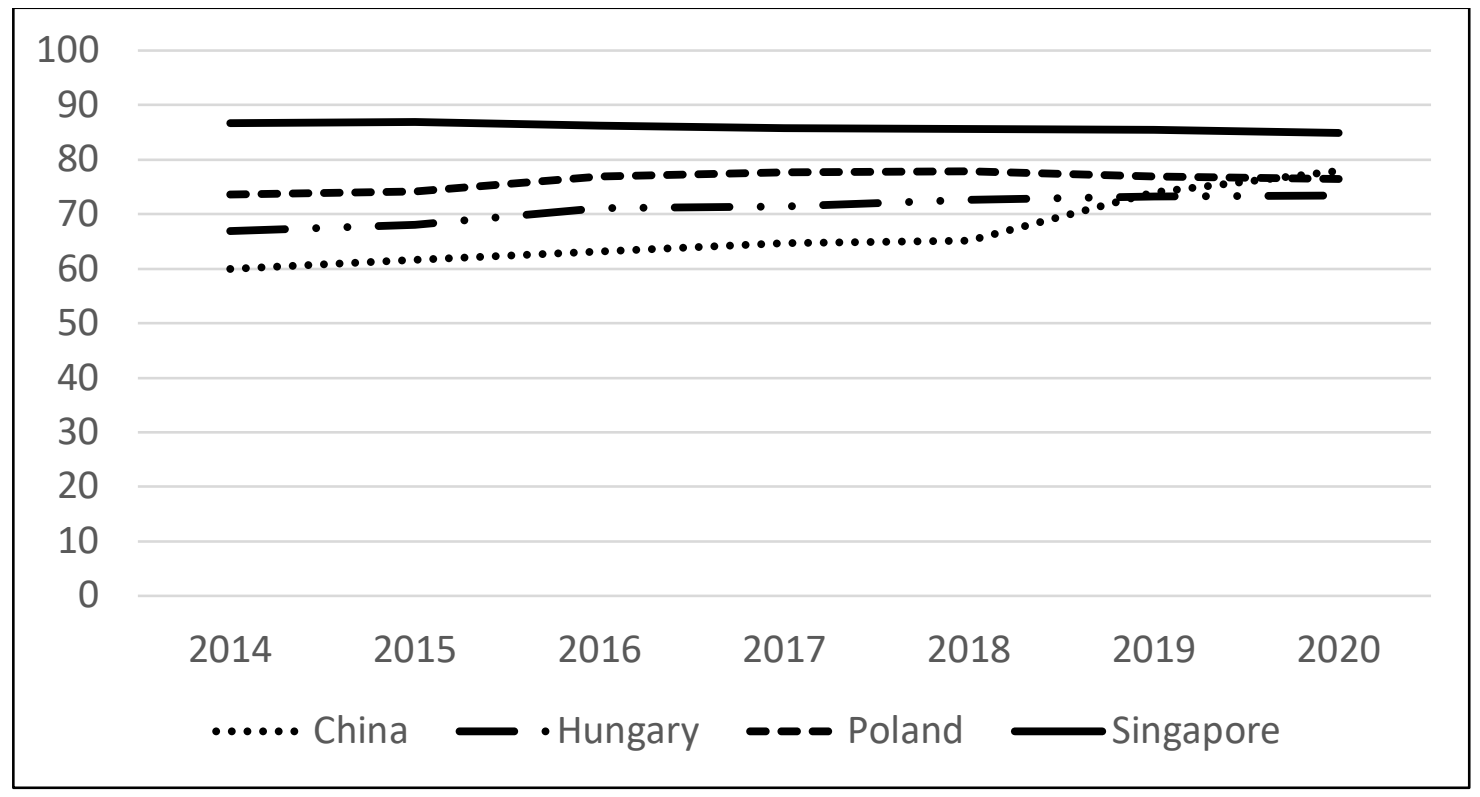

Figure 5: World Bank’s Doing Business Index Scores, 2014-2020

Source: World Bank 
Singapore has consistently had a very high doing business score-one that places it at the top of the world, as we will see below. China's raw score remained relatively constant from 1998 to 2011 but has improved significantly between 2014 and 2020. Poland's score increased significantly before the current PiS government, but both

Poland and Hungary's raw scores have continued to improve under right-wing populist rule. Authoritarian politics does not necessarily entail illiberal economic or business policy. Figure 6 shows how these countries rank in comparison with others across the world.

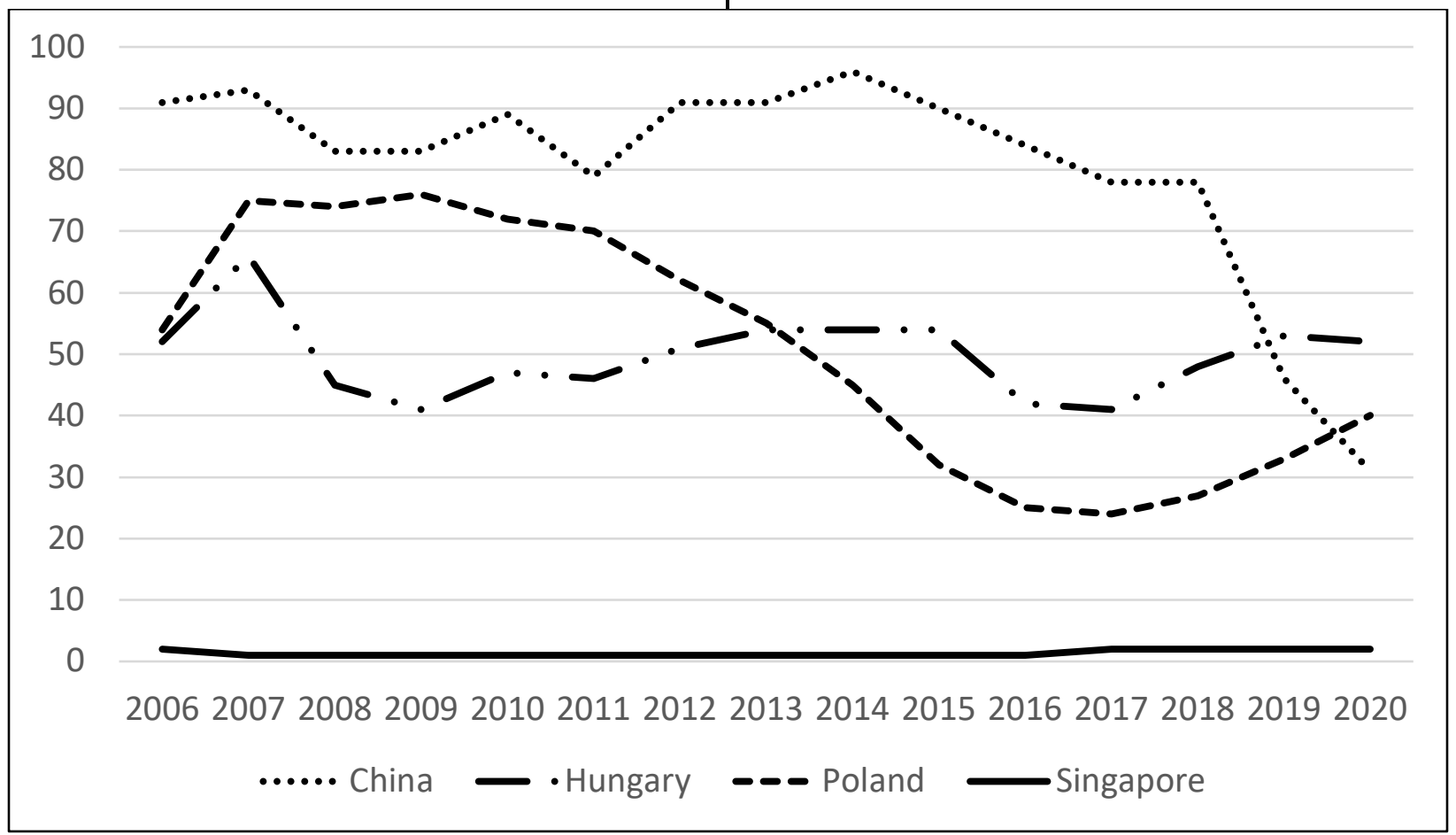

Figure 6: World Bank's Doing Business Index Rankings, 2006-2020

Source: World Bank

For ten of the fifteen years covered in Figure 6, Singapore has ranked \#1 in the world in the doing business index; in the remaining five 
years, Singapore ranked \#2 in the world.

Figure 6 shows that both Singapore's soft, technocractic authoritarianism and China's hard authoritarianism can be very good for business: China's ranking improved dramatically, from \#96 in 2014 and \#78 in 2018 to \#31 in 2020. China's hard authoritarianism has not stood in the way of growing business friendliness in recent years and decades.

The situation in right-wing populist Poland and Hungary is more mixed. Poland's ranking improved significantly from \#76 to \#32 in 2015, when the current PiS government came to power. Under right-wing populist rule, Poland's ranking continued to improve at first, before deteriorating in the last two years. In 2020, Poland was ranked lower than it was in 2015. Not all authoritarian and right-wing populist governments are business friendly. During the past decade, under Prime Minister Viktor Orbán's rule, Hungary's doing business index ranking has fluctuated around the same level. Hungary's ranking has not improved despite Orbán’s business-friendly orientation. ${ }^{27}$ 


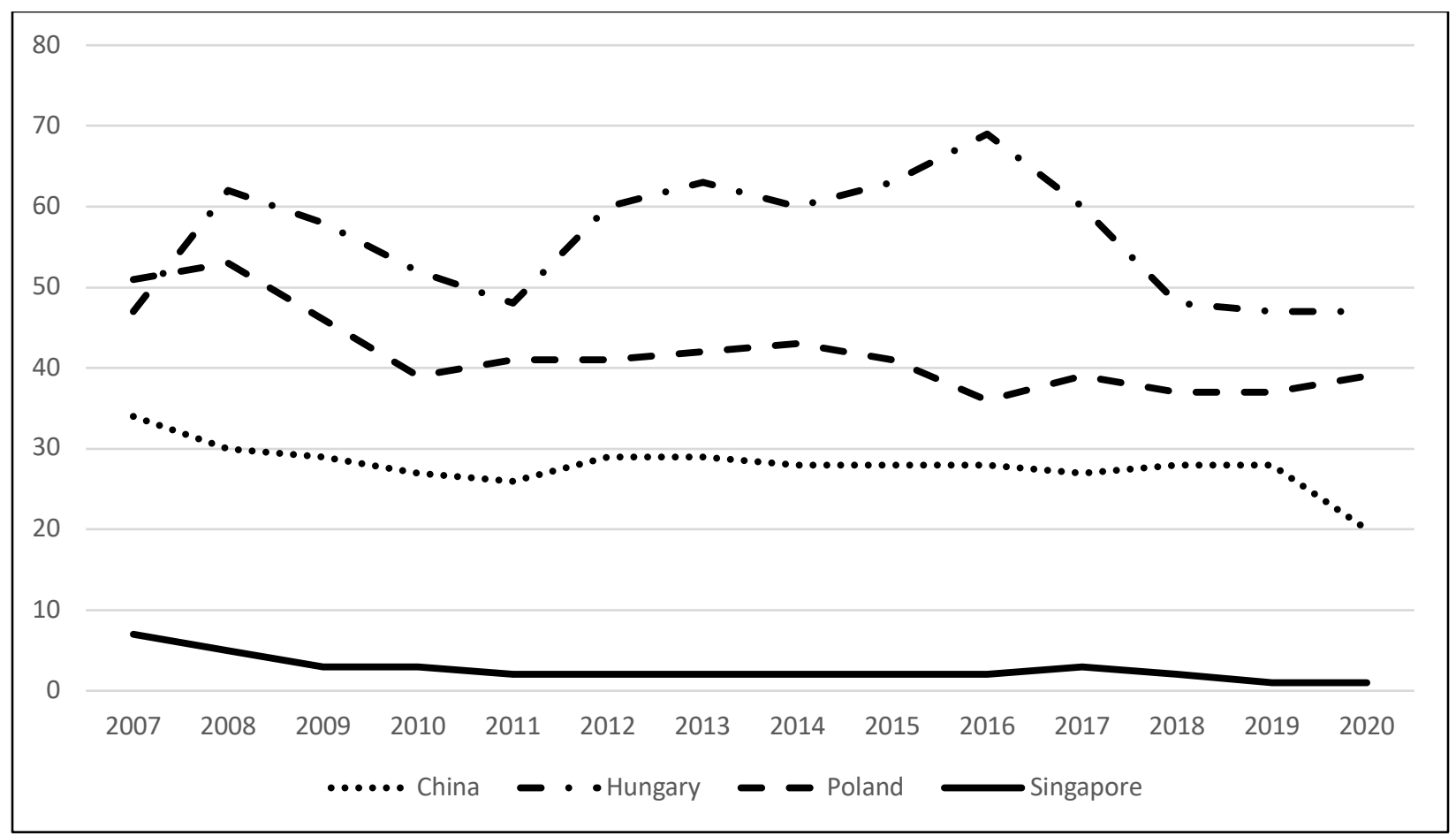

Figure 6: Global Competitiveness Index Ranking, 2007-2020

Source: World Economic Forum

While the value of

competitiveness is not undisputed, ${ }^{28}$ it is

important for companies in the

tradeable sector and in small, open

economies. Singapore has long been

ranked one of the world's most

competitive economies, and at the time

of writing, Singapore ranked \#1 in the

world. China's ranking has also

improved substantially. Poland and
Hungary's competitiveness rankings

both improved marginally following

right-wing populist rule.

Finally, we draw on the Global

Innovation Index rankings to

examine the

innovation performance of these four countries. The repression of political and civil liberties could plausibly have had a damaging effect in innovation. In 
this vein, five years ago, some scholars made the following remarks about China:

The needs of a middle income country, including greater reliance on innovation in technology and business models, and an increasingly diverse and sophisticated consumption demand, seem ill-suited for the still very sophisticated for the still very centralized model of Chinese state capitalism. Still, with its remarkable ability to reshape institutions, to experiment, and to use its size and diversity to its advantage, China has surprised us many times before. ${ }^{29}$

Figure 7 shows the innovation index rankings of these countries for the past dozen years.

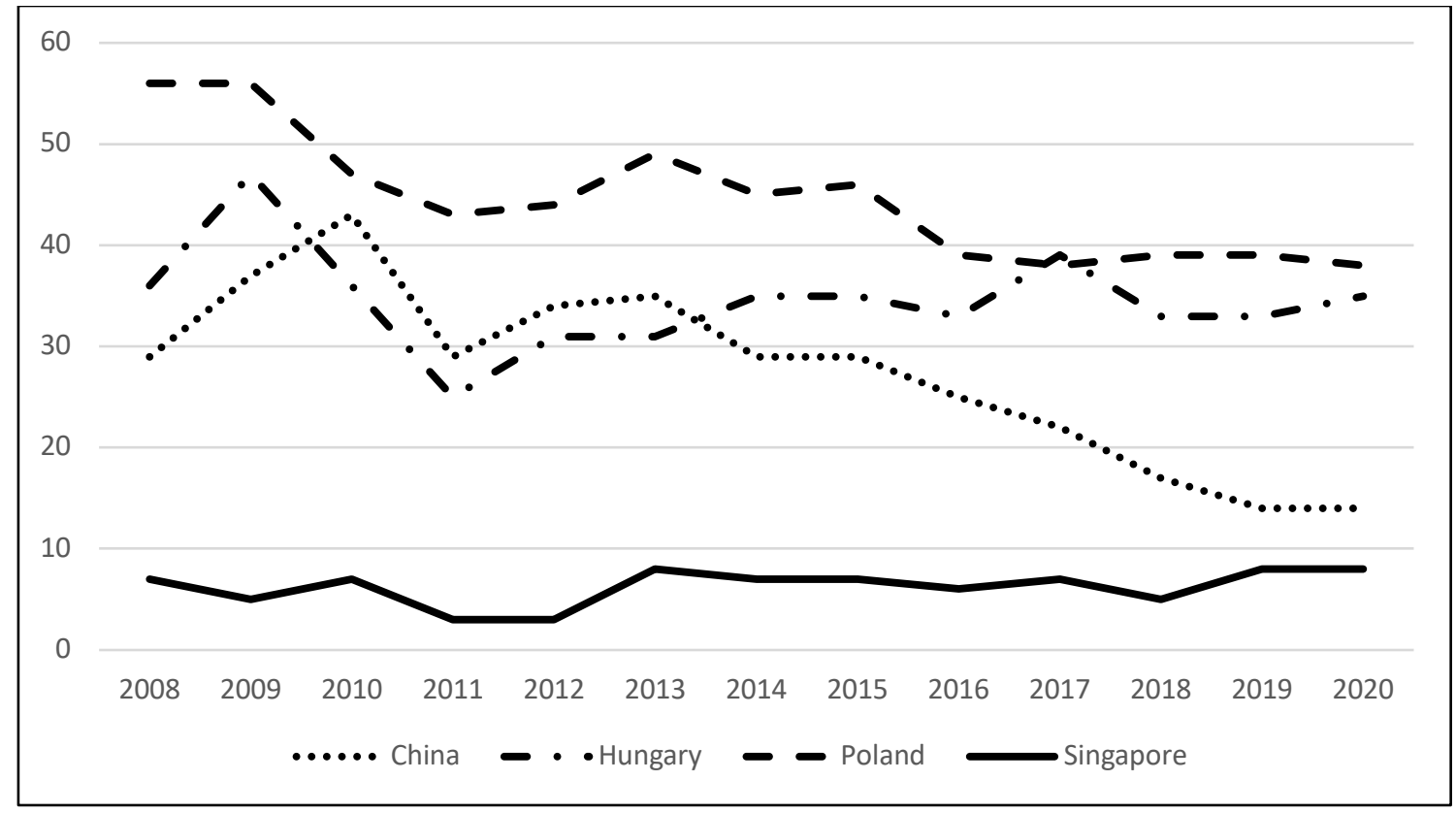

Figure 7: Global Innovation Index Rankings, 2008-2020

Source: Global Innovation Index 
The above authors' cautionary note was wise considering China's dramatic innovation performance improvement during the past five years. ${ }^{30}$ Singapore has fluctuated but remains solidly in the top 10. Poland's innovation performance has improved under PiS rule, while Hungary's ranking has remained around the same level under Orbán.

To sum up this section, the four authoritarian capitalist countries surveyed in this essay perform as follows: Singapore leads the world when it comes to competitiveness and the ease of doing business. Singapore's innovation performance is lower but consistently among the top 10 in the world. China's ease of doing business performance and ranking as well as its innovation index ranking have improved dramatically in recent years. Hungary and Poland's performances have wavered under right-wing populist rule, but they have not significantly deteriorated.

\section{Conclusions and Reflections}

Faced with the challenge posed by authoritarian capitalism, proponents of liberal democracy have consistently maintained that liberal democracy is better for business than authoritarian capitalism. We can see this in the following example:

Had Singapore been a liberal democracy, however, these difficulties might never have emerged in the first place. Even today, a freer society is likely to be more effective than more economic tinkering by the government in ensuring the country's future prosperity. That 
is the economic case for liberal democracy in Singapore. ${ }^{31}$

Since these remarks were made a decade ago, Singapore's performance has remained outstanding and China has made dramatic improvements. Hungary and Poland's performances have fluctuated, but they have not significantly deteriorated under rightwing populist rule. In short:

authoritarian leaders in these four countries have fostered a very good and increasingly attractive business environment.

The strong performance of authoritarian capitalist countries is not exactly news. After the Great Recession of 2008, there was recognition that, "One-party autocracy certainly has its drawbacks. But when it is led by a reasonably enlightened group of people ... it can also have great advantages." ${ }^{2}$ Further, in light of Singapore's success there is widespread acknowledgement that "liberal democracy is neither a necessary nor sufficient condition for good governance or prosperity."33

I wish to clarify that I am not arguing that authoritarian capitalism is necessarily successful or good for business. Autocrats and right-wing populists can be harmful and damaging; when businesspeople perceive them in this way, they can mobilize against them. 34 But this should not be our default assumption as authoritarian regimes have become increasingly business-friendly across the world.

I am also not claiming that businesspeople would opt for an authoritarian regime if given a full menu of options. Political and civil liberties are important to citizens, and many businesspeople have an interest in a liberal institutional environment which empowers them politically. Ceteris 
paribus-all other things being equalcapitalist firms may well prefer liberal democracy to authoritarian governance. However, in the real world, all other things are not equal. Authoritarian governments may be sufficiently repressive that domestic firms in these countries do not have much of a choice other than working with the powersthat-be.

Businesses from Western Europe and the United States could exit from Singapore, Hungary, Poland, or China if their investments in these countries were not worthwhile or engagement in these countries was too unsavory on account of corruption, repression, or other grounds-but they do not. Businesses' institutional preferences are malleable and business support can often be 'bought' with the right incentives, i.e. profits or rents. 35
Political developments in recent years have significantly weakened the business case for liberal democracy and, as a result, proponents of democracy may need to re-think some of their arguments. As Cherian George has suggested, the "good governance" practiced by authoritarian states such as Singapore significantly weakens the instrumental justification for democracy. ${ }^{6}$ Supporters of liberal democracy should not argue that liberal democracy is preferable because it is better for business than authoritarian capitalism, since it is far from obvious whether that is correct; in fact, the reverse may now be true.

The fact that authoritarian regimes have substantial business support suggests that democracy rests on a shaky political-economic foundation. To the extent that that is true, the future is wide open between 
alternative paths: a further deepening of authoritarian capitalism ${ }^{37}$ could lead to more improvement of the business environment, or a move away from capitalism could help to save democracy. It is too early to tell if liberal democracy can be stabilized and reconciled with capitalism and made to flourish again, as was the case in the post-war order 38 or whether the road ahead is instead "a long and painful period of cumulative decay."39 In any case, supporters of democracy will need to make a stronger case for its intrinsic, rather than its instrumental value. 40

\section{Author Bio}

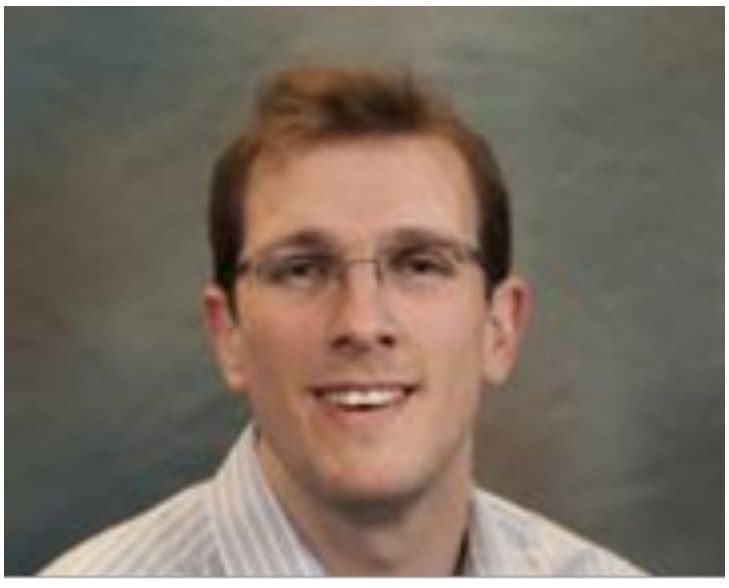

Daniel Kinderman holds a PhD

(Cornell University, 2011) and joined the Department of Science and International Relations at the University of Delaware in 2011. He is an Associate Professor and Director of European Studies at the University of Delaware. He specializes in comparative and international political economy and corporate social responsibility (CSR), with a geographical focus on Europe. He teaches courses on European politics, the European Union (EU), corporate social responsibility, comparative political economy and international political economy. His current research focuses on business responses to rightwing populism, the impact of responsible business associations on the CSR performance of their member companies and the relationship between 
CSR and political-economic institutions. Professor Kinderman has been a visiting scholar at the Social Science Research Center (WZB) in Berlin and at the Max
Planck Institute for the Study of Societies in Cologne, Germany.

\section{End Notes}

${ }^{1}$ Francis Fukuyama, The end of history and the last man. Simon and Schuster, 2006. ${ }^{2}$ Ian Bremmer, The End of the Free Market: Who Wins the War Between States and Corporations, Penguin, 2010, 3.

3 Larry Diamond, "Facing up to the democratic recession" Journal of Democracy 26.1 (2015): 141-155.

4 Steven Levitsky and Daniel Ziblatt. How democracies die. Crown, 2018; Thomas Piketty, Capital in the Twenty-First Century, Belknap Press of Harvard University Press, 2014, and Thomas Piketty, Capital and Ideology, Belknap Press of Harvard University Press, 2020; Adam Prezworski, Crises of democracy. Cambridge University Press, 2019.

5 Daron Acemoglu and Suresh Naidu, "Democracy does cause growth" Journal of Political Economy 127.1 (2019): 47-100.

${ }^{6}$ Daron Acemoglu and James A. Robinson. Why nations fail: The origins of power, prosperity, and poverty. Crown Business, 2012.

7 Ian Bremmer, The End of the Free Market: Who Wins the War Between States and Corporations, Penguin, 2010, 175.

8 Dorottya Sallai and Gerhard Schnyder. "What Is "Authoritarian" About Authoritarian Capitalism? The Dual Erosion of the Private-Public Divide in State-Dominated Business Systems." Business \& Society (2019).

9 Thomas Philippon, The great reversal: How America gave up on free markets. Harvard University Press, 2019. 
${ }^{10}$ Netina Tan, "Singapore: Challenges of 'Good Governance' Without Liberal Democracy." Governance and Democracy in the Asia-Pacific. Routledge, 2020, pp. 4873 .

${ }^{11}$ Raj Vasil, Governing Singapore: Democracy and national development. Routledge, 2020, p. 233

12 Kent E. Calder, Singapore: Smart city, smart state. Brookings Institution Press, 2016: 164-165.

${ }^{13}$ Michael A. Witt and Gordon Redding. "Authoritarian Capitalism." In: Michael A. Witt and Gordon Redding (eds.) The Oxford handbook of Asian business systems (2014), p. 26.

14 David Shambaugh, China's future. John Wiley \& Sons, 2016.

15 Hongyi Lai. China's governance model: Flexibility and durability of pragmatic authoritarianism. Routledge, 2016.

${ }^{16}$ Margaret Pearson, Meg Rithmire, and Kellee Tsai. "Party-State Capitalism in China." Harvard Business School Working Paper 21-065 (2020).

${ }^{17}$ Paul Lendvai, Orbán: Europe's new strongman (Oxford: Oxford University Press, 2018), p. 19, p. 150.

${ }^{18}$ Paul Lendvai, Orbán: Europe's new strongman (Oxford: Oxford University Press, 2018), p. 205, p. 53.

19 Balint Magyar, Post-communist Mafia state: The case of Hungary (Budapest: Central European University Press, 2016).

${ }^{20}$ Kim Lane Scheppele, Worst Practices and the Transnational Legal Order (or how to build a constitutional 'democratorship' in plain sight) Background Paper: Wright Lecture, University of Toronto, 2016.

${ }^{21}$ Takis Pappas, Populism and Liberal Democracy: A Comparative and Theoretical Analysis (Oxford: Oxford University Press, 2019), pp. 204-205. ${ }^{22}$ Péter Krekó and Zsolt Enyedi, "Explaining Eastern Europe: Orbán's Laboratory of Illiberalism” Journal of Democracy, Volume 29, Number 3, July 2018, pp. 39-51. 23 Jan-Werner Müller, What Is Populism? (Philadelphia: University of Pennsylvania Press, 2016).

24 For a useful account of Poland, see Wojciech Przybylski, "Explaining Eastern Europe: Can Poland's Backsliding Be Stopped?” Journal of Democracy 29, no. 3 (2018): 52-64. 
25 https://freedomhouse.org/reports/freedom-world/freedom-world-researchmethodology

${ }^{26}$ https://www.transparency.org/en/news/cpi-2019-global-highlights

${ }^{27}$ See Gábor Scheiring, The retreat of liberal democracy: Authoritarian capitalism and the accumulative state in Hungary Palgrave, 2020.

${ }^{28}$ Paul Krugman, “Competitiveness: a dangerous obsession" Foreign Affairs 73 (1994): 28.

29 Tsai, Kellee S., and Barry Naughton. "State capitalism and the Chinese economic miracle." B. Naughton, KS Tsai, eds Naughton, Barry, and Kellee S. Tsai, eds. State capitalism, institutional adaptation, and the Chinese miracle. Cambridge University Press, 2015. (2015): 21.

${ }^{30}$ See also Li, Zheng, et al. "China's 40-year road to innovation." Chinese Management Studies (2019); and Yu Zhou, William Lazonick, and Yifei Sun, eds. China as an innovation nation. Oxford University Press, 2016.

${ }^{31}$ Marco Verweij and Riccardo Pelizzo. "Singapore: does authoritarianism pay?." Journal of Democracy 20.2 (2009): 31.

32 Thomas Friedman, "Our one-party democracy" New York Times 8 (2009): A29. 33 Netina Tan, “Singapore: Challenges of 'Good Governance' Without Liberal Democracy." Governance and Democracy in the Asia-Pacific. Routledge, 2020, 50. 34 Daniel Kinderman, "German Business Mobilization against Right-Wing Populism." Politics \& Society (2020) https://doi.org/10.1177/0032329220957153

35 Future research could aim to compare the profit rates of firms under authoritarian capitalism and liberal democracy.

${ }^{36}$ Cherian George, "Neoliberal "Good Governance" in Lieu of Rights: Lee Kuan Yew's Singapore Experiment." In: Monroe Price and Nicole Stremlau, eds. Speech and Society in Turbulent Times. Cambridge University Press (2017): 114-130.

37 Peter Bloom, Authoritarian capitalism in the age of globalization. Edward Elgar Publishing, 2016.

${ }^{38}$ Sheri Berman, Democracy and dictatorship in Europe: from the Ancien Régime to the Present Day. Oxford University Press, 2019.

39 Wolfgang Streeck, How will capitalism end?: Essays on a failing system. Verso Books, 2016, p. 72. 
Authoritarian Capitalism and Its impact on Business Environment Daniel Kinderman

$4^{0}$ Amartya Kumar Sen, "Democracy as a universal value” Journal of Democracy 10.3 (1999): 3-17. 